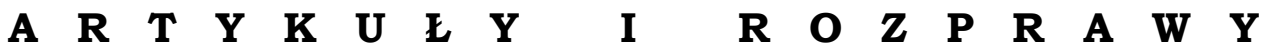

Krzysztof Tomasz Witczak

DOI: $10.33896 /$ PorJ.2020.10.1

(Uniwersytet Łódzki,

e-mail: krzysztof.witczak@uni.lodz.pl)

ORCID: 0000-0001-8895-974X

\section{ROZWAŻANIA NAD ETYMOLOGIĄ GROMU}

\section{WPROWADZENIE}

Polski apelatyw grom 'grzmot, huk piorunu' (< psł. *gromъ) ma, jak się wydaje, relatywnie jasna genezę. Jest to prastary derywat nominalny urobiony od czasownika grzmieć 'huczeć, dudnić (o odgłosie piorunu)' $(<$ psł. *grıměti), powstały już w dobie indoeuropejskiej i doskonale udokumento-

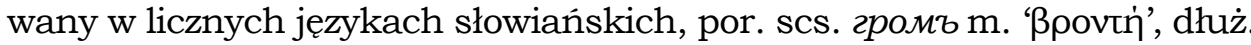
hrom m. 'grzmot, huk piorunu', cz. hrom m. 'ts.', sła. hrom m. 'ts.', ros. гром m. 'grom, piorun; wielki hałas, huk', brus. гром m. 'grzmot, huk, wielki hałas', ukr. zpiм m. 'ts.' [Trubačev 1980, 138; Sławski 2001, 228-229; Derksen 2008, 190]. Jeżeli zgodzimy się, że leksem psł. *gromヶ reprezentuje formację odziedziczona $z$ prajęzyka indoeuropejskiego, to należy wskazać najbliższe dlań odpowiedniki w innych pokrewnych językach. Podejmowany w niniejszej pracy problem badawczy polega na rozstrzygnięciu, czy czasownik prasłowiański sprowadza się do rdzenia ie. ${ }^{*} g^{h} r e m$ 'huczeć, grzmieć, dudnić; szaleć, wściekać się / dröhnen, wüten' [Pokorny 1959, 458-459; Rix 2001, 204], czy do rdzenia ie. * $g^{u}$ rem- 'huczeć, szumieć, brzmieć / brausen, tonen' [Rix 2001, 216]. Od obu powyższych morfemów leksykalnych utworzono niegdyś nazwy czynności (nomina actionis) z rdzennym wokalizmem apofonicznym ${ }^{*} o$, akcentowane na rdzeniu i należące do osnowy na *-o-. Odpowiednie formacje zachowały się najlepiej w języku greckim. Od pierwszego pierwiastka indoeuropejskiego urobiono grecki apelatyw xpójos m. 'wrzawa, trzask, rżenie' (< ie. * $g^{h}$ rómos $\leftarrow$ ie. * $g^{h}$ rem-), od drugiego gr. $\beta \rho o j$ os $\mathrm{m}$. 'wszelki hałas, trzask, huk piorunu, ryk, szum, huk; szał, wściekłość' (< ie. " $g^{u}$ rómos $\leftarrow$ ie. * $g^{u}$ rem-). Teoretycznie można zestawić leksem psł. *grom` m. 'grzmot, piorun, huk piorunu' zarówno $z$ pierwszym, jak i drugim greckim rzeczownikiem. ${ }^{1}$ Która $z$ dwu wskazanych tu ewentualności jest poprawna? W niniejszym artykule chciałbym odpowiedzieć na to pytanie.

${ }^{1}$ Zob. Meillet [1905, 218]. 


\section{TRZY RDZENIE INDOEUROPEJSKIE ${ }^{*} B^{H} R E M-,{ }^{*} G^{H} R E M-I{ }^{*} G{ }^{U} R E M-$}

Indoeuropeiści wyróżnili trzy rdzenie werbalne o podobnej semantyce i bardzo zbliżonej budowie, które różnią się tylko nagłosowym fonemem: 2.1. ie. ' 'bhrem- 'mruczeć, brzęczeć; ryczeć, wyć / brummen, brüllen' [Pokorny 1959, 142-143; Rix 2001, 94];

2.2. ie. * $g^{h} r e m$ - 'huczeć, grzmieć, dudnić; szaleć, wściekać się / dröhnen, wüten' [Pokorny 1959, 458-459; Rix 2001, 204];

2.3. ie. ' $g^{u} r e m$ - 'huczeć, szumieć, brzmieć / brausen, tonen' [Rix 2001, 216].

Rozwój fonetyczny, typowy dla poszczególnych języków indoeuropejskich, sprawił, że w dobie współczesnej niełatwo jest rozstrzygnąć, czy dany wyraz rozwinał się $z$ pierwszego, drugiego, czy trzeciego morfemu leksykalnego. Poniżej zestawiono w postaci tabelarycznej kontynuanty nagłosowych fonemów ${ }^{*} b^{h_{-}},{ }^{*} g^{h_{-}}$oraz ${ }^{*} g^{u}$ - w poszczególnych ugrupowaniach indoeuropejskich:

Tabela 1. Kontynuanty fonemów ie. ${ }^{*} b^{h_{-},}{ }^{*} g^{h_{-}},{ }^{*} g^{\mu_{-}}$ w pozycji przed spółgłoska płynną *r

\begin{tabular}{|c|c|c|c|c|}
\hline Języki & ${ }^{*} \boldsymbol{b}^{h}$ & ${ }^{*} g^{h_{-}}$ & ${ }^{*} \boldsymbol{g}^{u}-$ & Komentarz \\
\hline albański & $b-$ & $g-$ & $g-$ & Brak odróżnienia rdzeni ${ }^{*} g^{h} r e m-i{ }^{*} g^{u} r e m-$ \\
\hline anatolijskie & $* b-$ & $* g-$ & ${ }^{*} g^{u}-$ & \\
\hline bałtyckie & $b-$ & $g^{-}$ & $g^{-}$ & Brak odróżnienia rdzeni ${ }^{*} g^{h} r e m-\mathrm{i}{ }^{*} g^{u}$ rem- \\
\hline celtyckie & $b-$ & $g-$ & $b-$ & Brak odróżnienia rdzeni ${ }^{*} b^{h} r e m-\mathrm{i} * g^{u} r e m-$ \\
\hline germańskie & $b-$ & $g^{-}$ & $* k^{u-}$ & \\
\hline grecki & $p h-(\varphi-)$ & $k h-(\mathrm{x}-)$ & $b-(\beta-)$ & \\
\hline indyjskie & $b h-$ & $g h-$ & $g^{-}$ & \\
\hline irańskie & $b-$ & $g^{-}$ & $g-$ & Brak odróżnienia rdzeni ${ }^{*} g^{h} r e m-i{ }^{*} g^{u} r e m-$ \\
\hline łaciński & $f-$ & g- & $g-$ & Brak odróżnienia rdzeni ${ }^{*} g^{h} r e m-\mathrm{i}{ }^{*} g^{u} r e m-$ \\
\hline słowiańskie & $b-$ & g- & $g^{-}$ & Brak odróżnienia rdzeni ${ }^{*} g^{h} r e m-\mathrm{i} * g^{u} r e m-$ \\
\hline tocharskie & $p-$ & $\mathrm{k}-$ & $k-$ & Brak odróżnienia rdzeni * $g^{h} r e m-$ i * $g^{u} r e m-$ \\
\hline
\end{tabular}

Źródło: opracowanie własne.

Z powyższego zestawienia wynika, że jedynie w czterech podgrupach językowych (anatolijskiej, germańskiej, greckiej i indyjskiej) można precyzyjnie odróżnić kontynuanty trzech rozpatrywanych rdzeni indoeuropejskich. W pozostałych podgrupach musiała nastapić identyfikacja 
rdzeni pod względem fonologicznym, co mogło powodować kontaminację dwóch odmiennych rdzeni, a także eliminację jednego $z$ nich. Omówmy w pierwszej kolejności poświadczenia w językach celtyckich.

Język (średnio)walijski poświadcza czasownik brefu 'beczeć, ryczeć, wyć' < celt. *bremō [Matasović 2009, 76]. Nie potrafimy jednak precyzyjnie wskazać, czy walijska formację werbalna należy zestawiać $z$ łacińskim czasownikiem fremō 'wydawać głuchy dźwięk, huczeć, dudnić, ryczeć, wyć, szumieć, brzęczeć, rżeć, chrapać, warczeć, świszczeć; szemrać; głośno wołać, ogłaszać' (< ie. * 'bh remō), czy raczej z gr. $\beta \rho \varepsilon \dot{\mu} \mu \omega$ 'ryczeć, huczeć, dźwięczeć, chrzęścić; wściekać się, krzyczeć, szemrać, narzekać, zawodzić; rozbrzmiewać' (< ie. * $g^{u}$ remō). Większość badaczy zakłada milcząco pierwszą derywację [Pokorny 1959, 143; Rix 2001, 94; Matasović 2009, 76], chociaż drugie zestawienie jest równie prawdopodobne pod względem fonologicznym, jak i semantycznym. ${ }^{2}$ Nie da się wykluczyć ewentualności, że w językach celtyckich nastapiła kontaminacja dwóch odmiennych rdzeni indoeuropejskich (celt. *brem-< ie. ${ }^{*} b^{h} r e m-\mathrm{x}{ }^{*} g^{u} r e m-$ ).

W polszczyźnie zachowała się opozycja dwóch rozpatrywanych rdzeni: brzmieć vs grzmieć (< psł. *brımèti vs *grıměti). Potrafimy precyzyjnie wskazać, że czasownik brzmieć ostatecznie sprowadza się do indoeuropejskiego rdzenia werbalnego ${ }^{*} b^{h} r e m$-, ale na bazie czysto fonetycznej nie da się stwierdzić, czy pol. grzmieć reprezentuje ie. ${ }^{*} g^{h} r e m-$, czy też ie. " $g^{u} r e m-$. Aby wskazać jednoznaczna derywację, trzeba przeprowadzić drobiazgowa analizę semantyczna i strukturalną. To samo należy uczynić w odniesieniu do innych języków indoeuropejskich (głównie satemowych), które utracily dystynktywny charakter fonemów welarnych i labiowelarnych, czyli zidentyfikowały ze soba fonemy ie. ${ }^{*} g^{h}$ oraz ${ }^{*} g^{u}$. Poza językami słowiańskimi rozróżnienie to utraciły języki bałtyckie, irańskie, tocharskie, albański, a w tym specyficznym przypadku także język łaciński. ${ }^{3}$

2 Julius Pokorny [1959, 143] nie odrzuca zestawienia grecko-celtyckiego, ale nieco inaczej na nie spogląda. Przyjmuje mianowicie nieregularna utratę przydechu w języku greckim: $\beta \rho \dot{\varepsilon} \mu \omega\left(<{ }^{*}\right.$ bremō $<$ ie. ${ }^{*} b^{h}$ remō).

3 Język łaciński w większości wypadków zachował dystynkcję pomiędzy ie. ${ }^{*} g h$ (> łac. $h$ - w nagłosie, $-g$ - w śródgłosie) oraz ie. ${ }^{*} g^{u}$ (> łac. $v$ w nagłosie przed samogłoska i w pozycji interwokalicznej, ale -gu-w śródgłosie w pozycji po spółgłosce nosowej). W pozycji przed *-r-oba indoeuropejskie fonemy daja identyczna kontynuację, czyli łac. gr-, por. łac. grāmen n. 'trawa' $(<$ ie. *ghras-, por. ang. grass); łac. grātus adi. 'wdzięczny, miły, pożądany' (< ie. * $g^{u} r$ Htos); łac. gravis

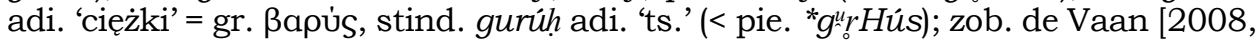
269-272]. 


\section{ATESTACJA I SEMANTYKA INDOEUROPEJSKIEGO RDZENIA * $G^{H} R E M$ -}

Zdaniem Juliusa Pokornego [1959, 458-459], rdzeń ie. * $g^{h} r e m-z a-$ chował się w pięciu indoeuropejskich grupach językowych: irańskiej, greckiej, germańskiej, bałtyckiej i słowiańskiej. Materiał irański, bałtycki i słowiański nie jest jednoznaczny i może odnosić się także do alternatywnego rdzenia ie. ${ }^{*} g^{u} r e m-$, zatem nasze rozważania ograniczymy do greckiego i germańskiego materiału leksykalnego.

W języku greckim morfem leksykalny ${ }^{*} g^{h} r e m$-zachował się w trzech formacjach werbalnych: $x \rho \varepsilon \mu \varepsilon \dot{\theta} \omega \omega$ 'rżeć (o koniu)', x $\rho \varepsilon \mu i \zeta \omega$ 'ts.' oraz

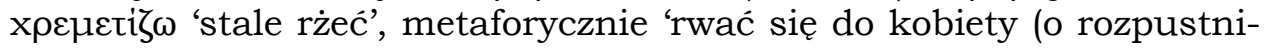
kach)'. Oprócz formacji czasownikowych poświadczone sa liczne dery-

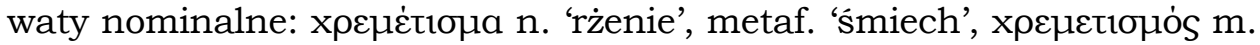

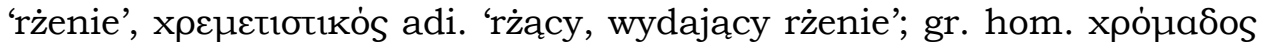
m. 'zgrzytanie, zgrzyt (o zębach)' oraz xpójos m. 'wrzawa; trzask; rżenie' (wyraz relatywnie rzadki, zachowany jedynie w dwóch glosach u późno-

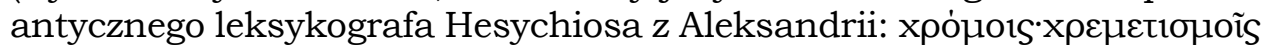

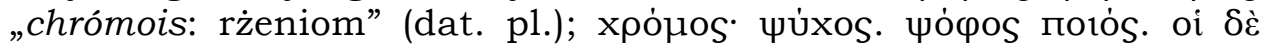

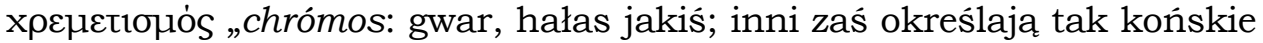
rżenie"). Wszystkie powyższe atestacje wyraźnie wskazuja, że czasownik grecki opisywał odgłos wydawany przez konia (tj. rżenie), zwłaszcza podczas rui (jak tego dowodzi metafora erotyczna odnoszaca się do ludzi).

Germański materiał leksykalny poświadcza trzy pokrewne formacje: 3.1. czasownik prymarny *grimman- 'szaleć, gniewać się': stang. grimman 'szaleć, ryczeć; pędzić (jak szalony)', stsaks. grimman 'szaleć', śrwniem. grimmen 'szaleć, wyć, ryczeć' < ie. *ghrem- [Pokorny 1959, 458; Kroonen 2013, 190];

3.2. pgerm. *gramjan- 'podburzyć, zirytować, rozgniewać' (pierwotnie verbum causativum *ghrom-éie- 'spowodować, że ktoś szaleje, gniewa się): goc. gramjan 'rozgniewać, rozzłościć'; stnord. gremja 'uczynić złym, gniewnym'; stang. gremian 'rozgoryczyć, zwymyślać'; śrdniem. gremmen 'pogniewać się'; stwniem. grem $(m)$ en 'rozgniewać, rozzłościć, rozgoryczyć'; niem. grämen 'martwić, trapić, irytować' [Kroonen 2013, 186];

3.3. przymiotnik pgerm. *gramaz 'zły, gniewny': stnord. gramr adi. 'rozzłoszczony, wrogi'; stang. gram adi. 'zły, wściekły, wrogo usposobiony', stsaks. gram adi. 'ts.', stwniem. gram adi. 'ts.', śrwniem. 'zły, gniewny, niezadowolony'< ie. "ghromós [Pokorny 1959, 458].

Wymienione powyżej wyrazy germańskie opisuja bez watpienia stan emocjonalny człowieka lub jakiegoś zwierzęcia (zwłaszcza podczas rui, rozdrażnienia lub niebezpieczeństwa). Zbieżność semantyczna $z$ wyżej przedstawionym materiałem greckim jest dość znacząca. 


\section{RDZENं ${ }^{*} G^{U}$ REM- W JĘZYKU GRECKIM}

Grecki czasownik $\beta \rho \varepsilon \dot{\mu} \mu \omega$ pokazuje następujące znaczenia: 'ryczeć, huczeć (o morzu i falach morskich); dźwięczeć, chrzęścić (o broni); wściekać się, krzyczeć (o ludziach), szemrać, narzekać, zawodzić; rozbrzmiewać (o lirze)' [Abramowiczówna 1958, 443]. Teksty antyczne poświadczaja również formację iteratywną $\beta \rho 0 \mu \varepsilon \dot{\omega} \omega$ 'brzęczeć (o muchach); huczeć (o wietrze)' [Abramowiczówna 1958, 444]. Pradawnym derywatem jest także nazwa czynności (nomen actionis) ßpójos m. 'wszelki hałas, trzask (o ogniu); huk piorunu; ryk (np. jeleni); szum, huk (o morzu); szał, wściekłość', reprezentująca archetyp ie. " $g^{u}$ rómos.

Od rdzenia * ${ }^{\prime}{ }^{u}$ rem- utworzono ponadto formację intensywno-itera-

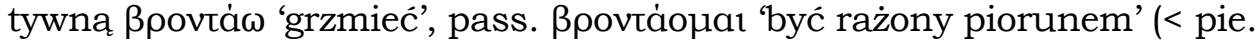

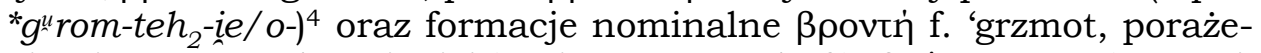
nie piorunem, odrętwienie' (< pie. " $g^{u}$ rom-téh f.) $^{2}$, ßpóvtnua n. 'grzmot',

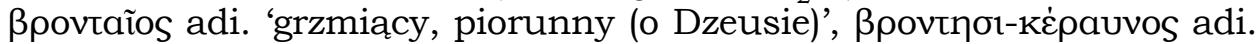
'zsyłający grzmoty i pioruny (o chmurze burzowej)' [Abramowiczówna 1958, 444].

Przegląd greckiego materiału leksykalnego dowodzi, że rdzeń * $g^{u} r e m$ wiąże się przede wszystkim ze zjawiskami naturalnymi, zwłaszcza atmosferycznymi (takimi jak ryk wzburzonego morza; nawałnica $z$ grzmotami i piorunami). Mamy więc udokumentowana dość wyraźną opozycję semantyczną występująca pomiędzy rdzeniami ie. ${ }^{*} g^{h} r e m-$ oraz ${ }^{*} g^{u} r e m-$. Możemy zatem przystapić do kolejnego etapu naszych rozważań i sprawdzić, jak należy klasyfikować materiał języków irańskich, bałtyckich i słowiańskich.

\section{RDZEŃ *GRAM- W JĘZYKACH IRAŃSKICH}

Irański materiał leksykalny pokazuje generalnie uderzająca zbieżność z germańskimi odpowiednikami, wyliczonymi w podrozdziale 3.:

5.1. awest. gram- 'rozzłościć, rozgniewać, być rozsierdzonym, żywić złość / ergrimmen, Grimm hegen', part. praes. act. gramant- 'żywiący złość', part. perf. pass. granta- 'rozsierdzony, zagniewany' [Bartholomae 1904, 529; chot. grąñ- 'warczeć, burczeć / to growl'; chorezm. $\gamma m$ - 'gruchać, śpiewać (o ptakach)'; iszk. yərənd 'besztać, łajać, złorzeczyć / to scold'; oset. (iroń.) qyrnyn, (dig.) ğirnun 'śpiewać; szczekać (o psach)' < irań. *gram- [Cheung 2007, 122; Rastorgueva, Edelman 2007, 284-286];

5.2. sogd. '(n)yr'm [agrām] 'zniesławiać, rzucać oszczerstwa'< irań. *ham-grāmaya- (verbum causativum), por. pgerm. *gramjan- (3.2.);

4 Szerzej o formacjach werbalnych i nominalnych $z$ cecha pie. ${ }^{*} t e h_{2}-z_{0}$. Witczak [2017, 209-222]. 
5.3. npers. Yaram m. 'złość, zażarty gniew' (< irań. *grama- m.) wykazuje znacząca zgodność semantyczną i formalna $z$ przymiotnikiem pgerm. *gramaz 'zły, gniewny' (3.3.);

5.4. sogd. yr'ndyy adi. 'zły, gniewny, rozsierdzony'; yrm'wy 'kara cielesna, ukaranie'; tadż. dial. (płd.) Y৮rınd 'zemsta, odwet' [Rastorgueva, Edelman 2007, 284].

W językach irańskich można ponadto wyróżnić skromne ślady rdzenia ie. * $g^{u} r e m-$, które zachowały się w następujących formacjach werbalnych i nominalnych:

5.5. npers. ğurunbidan, dial. (gaz) qurumb-/ qurumbā 'grzmieć, ryczeć, wrzeszczeć / to thunder, roar'; npers. garmidan 'grzmieć, ryczeć, wpaść w namiętność / to thunder, roar, fly in a passion', bal. grandit-/grand- 'grzmieć / to thunder', afg. var-éğ- / var-ed- 'krzyczeć, wrzeszczeć, grzmieć / to roar, thunder'< irań. "gram- [Cheung 2007, 122];

5.6. orosz. grand 'grzmot, grom; burza, nawałnica / гром, гроза' [Rastorgueva, Edelman 2007, 286], bal. garand 'grzmot (piorunu) / / thunder', sist. grand 'ts.' [Bailey 1979, 84; Cheung 2007, 122; Rastorgueva, Edelman 2007, 173] < irań. *grantā f. 'grzmot, grom, burza $z$ piorunami'.

Nie ulega wątpliwości, że trzy ostatnie terminy (5.6.), sprowadzające się do irań. 'grantā f. 'grzmot, grom, burza z piorunami', należy zestawić $z$ greckim leksemem ßpovtn่ f. 'grzmot, porażenie piorunem, odrętwienie' (< pie. * 'gurom-téh ${ }_{2}$ f. 'grzmot, grom').

\section{BAETYCKI MATERIAL LEKSYKALNY}

Leksyka bałtycka zawiera doskonale umotywowane ślady rdzenia ie. * ${ }^{u}$ rem-, opisującego zjawiska atmosferyczne:

6.1. lit. gruméti 'grzmieć, dudnić (o odgłosie piorunu w czasie burzy), huczeć', gruménti 'głucho dudnić (o odległych grzmotach)', igruméti 'wejść, wjechać $z$ hałasem', sugruméti 'zejść się, zebrać się w zgiełku' [Smoczyński 2007, 205-206; Derksen 2015, 190-191]; stprus. (EV) grumins 'grzmot odległej burzy, Dunreyn' lub 'mżawka, deszcz z grzmotami' [Derksen 2015, 558];

6.2. lit. graméti 'padać $z$ trzaskiem, upaść $z$ hukiem, runać $z$ hałasem' [Derksen 2015, 185].

Inne zestawione przez Wojciecha Smoczyńskiego [2007, 205-206, s.v. gruméti] wschodniobałtyckie formacje werbalne lub nominalne maja, jak się wydaje, mocno odmienny charakter i nawiazuja przypuszczalnie do konkurencyjnego rdzenia ${ }^{*} g^{h} r e m$-, opisującego stan emocjonalny człowieka. Do tego gniazda słowotwórczego skłonny jestem zaliczyć następujace formacje: 
6.3. łot. gremt 'mruczeć, mówić podniesionym głosem', refl. gremties 'odgrażać się, grozić'; lit. grumóti 'grozić, straszyć zapowiedzia czegoś złego', gruménti tr. 'napominać, przestrzegać, grozić, odgrażać się';

6.4. łot. gruma f. 'uraza'.

Nawet przy pobieżnej analizie faktów bałtyckich dostrzegamy prawdopodobna kontaminację dwu odrębnych rdzeni indoeuropejskich ${ }^{*} g^{u} r e m$ - oraz ${ }^{*} g^{h}$ rem-. W niektórych przypadkach można mieć uzasadnione wątpliwości, do którego rdzenia trzeba przypisać poniższe bałtyckie formy, np.:

6.5. lit. graméti 'biec na przełaj', 'zapadać się w bagnie, grzęznąć' [Smoczyński 2007, 206], lit. garméti 'hurmem, kupa iść i hałasować', 'grzęznać, zatapiać się (w bagnie, topieli)', 'szemrać (o wodzie); mruczeć; mamrotać', lit. gar̃malas m. 'wrzask, krzyk', garmãlius m. 'krzykacz, płaksa (o dziecku)', garmaliúoti ‘bulgotać, gulgotać (o gotującej się wodzie, kartoflach; o chlupocie wody na bagnie pod stopami chodzacego; o płukaniu gardła)' [Smoczyński 2007, 160]. ${ }^{5}$

\section{SEMANTYKA SEOWIAŃSKIEGO MATERIALU LEKSYKALNEGO}

Ponieważ materiał leksykalny języków słowiańskich, odnoszacy się do apelatywu *gromъ i zwiazanych $z$ nim formacji, został już zebrany i opublikowany w dostępnych słownikach porównawczych i etymologicznych [Trubačev 1980; Sławski 2001], w niniejszej pracy ograniczyłem się do wyliczenia prasłowiańskich prototypów, zrekonstruowanych w ósmym tomie Słownika prasłowiańskiego, poprzedzonych jedna przykładowa jednostka polska lub inną reprezentatywna forma słowiańską:

7.1. pol. grzmieć < psł. *grıměti 'głośno, hucznie rozbrzmiewać, huczeć, grzmieć (o odgłosie burzy)’ [Sławski 2001, 265-266; Trubačev 1980, 163-164], pierwotny czasownik stanu (verbum essivum);

7.2. pol. przestarz. grzmotać 'bić mocno, walić, uderzać' < psł. *grbmotati 'powodować lub wydawać głośne dźwięki, okrzyki' [Sławski 2001, 267], verbum intensivum od psł. *grıměti;

5 Niektóre formy bałtyckie, wyszczególnione powyżej (w podpunkcie 6.5.), nie należa, jak mniemam, ani do rdzenia * $g^{u} r e m$-, ani ${ }^{*} g^{h} r e m-$, ale wiążą się $z$ osobnym rdzeniem ie. *grem- 'być wilgotnym, zanurzać (w wodzie), tonać / feucht (sein), untertauchen, untersinken' [Pokorny 1959, 405], por. lit. grimti 'zapaść się, ugrzęznąć, zanurzyć się, pogrążyć się, utonąć, łot. grimt 'pogrążać się, tonąć (na grząskim terenie)' [Smoczyński 2007, 201]. Należy w tym miejscu podkreślić, że gocki wyraz qrammipa f. 'wilgoć' zdaje się sugerować, że indoeuropejski morfem leksykalny *grem- (tak rekonstruowany w słowniku J. Pokornego) zawierał w nagłosie spółgłoskę labiowelarną dźwięczną * $g^{u}$ - (skąd goc. q-), która uległa uproszczeniu do ${ }^{*} g$ przed spółgłoska płynna ${ }^{*} r$ w innych językach germańskich, por. stnord. krammr adi. 'wilgotny, częściowo roztopiony (o śniegu w czasie odwilży)', norw. krammr adi. 'ts.' [Kronnen 2013, 300-301]. Czyżby zatem w prajęzyku indoeuropejskim istniały dwa homonimiczne pierwiastki ${ }^{*} g^{u} r e m$-? 
7.3. pol. grzmot < psł. *gromot' $\mathrm{m}$. "huk towarzyszacy błyskawicom i wyładowaniom elektrycznym w powietrzu, grom, tonitrus': 'tępy dźwięk, huk przypominający wyładowanie atmosferyczne, fragor' [Sławski 2001, 267-268] $\leftarrow$ psł. *grımotati; nieco inny wywód proponuje Oleg N. Trubačev [1980, 164], który zakłada derywację od czasownika psł. *grıměti za pomoca przyrostka *-ot‘;

7.4. stcz. hr̈imati 'grzmieć' < psł. *grimati 'grzmieć, huczeć' [Sławski 2001, 216], verbum intensivum od psł. *grıměti. Zdaniem O.N. Trubačeva [1980, 129], formacja ta reprezentuje czasownik iteratywno-duratywny;

7.5. pol. grom < psł. *gromb m. 'grzmot, piorun, huk piorunu, tonitrus' [Sławski 2001: 228-229; Trubačev 1980, 138], pierwotne nomen actionis;

7.6. strus. громґти 'grzmieć' < psł. *gromèti 'grzmieć, huczeć, tonare' [Sławski 2001, 227] = lit. graméti 'padać, upaść $z$ hukiem, runąc $z$ hałasem'. Prawdopodobny odpowiednik litewski gwarantuje bałtosłowiański charakter dyskutowanej formacji werbalnej;

7.7. pol. gromić < psł. *gromiti 'zadawać porażkę, rozbijać, zwyciężać, unicestwiać, niszczyć, działać jak grom', 'grzmieć, huczeć' [Sławski 2001, 227; Trubačev 1980, 137], verbum factitivum od psł. *gromъ. Można też psł. *gromiti (w sensie 'grzmieć, huczeć) rozpatrywać jako formację iteratywna na -eie-;

7.8. głuż. hromotać 'huczeć, grzmieć' < psł. (płn.) *gromotati (verbum intensivum) 'grzmieć, huczeć, tonare' [Sławski 2001, 228] $\leftarrow$ psł. *gromiti;

7.9. pol. (XVI w.) gromot 'huk, trzask, łomot, potężny odgłos' < psł. "gromot'b m. 'huk, grzmot, hałas' [Sławski 2001, 228; Trubačev 1980, 137-138] $\leftarrow$ psł. *gromotati;

7.10. pol. gromowy < psł. *gromovヶ adi. 'dotyczacy gromu, związany $z$ gromem' [Sławski 2001, 228; Trubačev 1980, 138] $\leftarrow$ psł. *gromъ;

7.11. pol. dawne gromny 'gromki, bardzo głośny, huczny; wytwarzajaccy pioruny'< psł. *grombn` adi. 'głośny jak grom, gromki, grzmiacy, huczny, tonans' [Sławski 2001, 229; Trubačev 1980, 139] $\leftarrow$ psł. *grom`.

Wszystkie wyliczone formacje prasłowiańskie jednoznacznie wiążą się ze zjawiskami atmosferycznymi ( $\mathrm{z}$ burza, nawałnica pełna grzmotów i błyskawic), wtórnie dopiero $z$ działalnością człowieka. Nie kojarza się natomiast $z$ gwałtownymi reakcjami emocjonalnymi człowieka lub zwierzęcia, takimi jak gniew, złość, wściekłość, niezadowolenie, pociagg płciowy. Te obserwacje prowadza zatem do konkluzji, że wszystkie formacje prasłowiańskie należy - w ślad za opinią Antoine’a Meilleta [1905, 218; 1907, 366] - łączyć $z$ rdzeniem ie. * ${ }^{\prime} g^{u} r e m$ - (a nie $z$ ie. ${ }^{*} g^{h} r e m-$, jak to czyni większość współczesnych etymologów).

6 Warto zwrócić uwagę, że jeszcze w 1893 r. francuski indoeuropeista akcep-

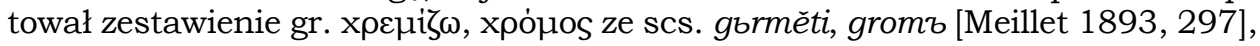




\section{PODSUMOWANIE}

Analiza semantyczna i morfologiczna indoeuropejskiego materiału leksykalnego pozwala na wyciagnięcie następujących wniosków:

8.1. Czasownik psł. *grımèti 'głośno, hucznie rozbrzmiewać, huczeć, grzmieć (o odgłosie burzy)' reprezentuje prajęzykowe verbum essi-

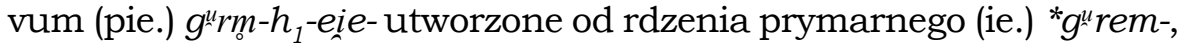

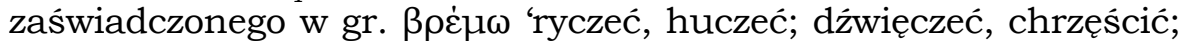
wściekać się, krzyczeć, szemrać, narzekać, zawodzić; rozbrzmiewać'.

8.2. Psł. *grom๖ $\mathrm{m}$. 'grzmot, piorun, huk piorunu' ma dokładny odpowiednik w gr. ßpójos m. 'wszelki hałas, trzask; huk piorunu; ryk; szum, huk; szał, wściekłość' i wywodzi się z praformy ie. " $g^{u}$ rómos m. 'grzmot, huk piorunu, hałas' (pierwotne nomen actionis). Zestawienie wyrazu prasłowiańskiego $z$ gr. xpópos m. 'wrzawa, trzask, rżenie' należy uznać za wątpliwe $z$ semantycznego punktu widzenia.

8.3. Psł. *gromiti 'grzmieć, huczeć', także 'zadawać porażkę, rozbijać, zwyciężać, unicestwiać, niszczyć, działać jak grom' można z po-

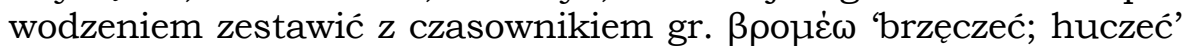
(< pie. * $g^{u}$ rom-éie-).

8.4. Prasłowiańskie verbum intensivum *gromotati 'grzmieć, huczeć, tonare' można skojarzyć $z$ podobna formacja poświadczoną $w$ języku

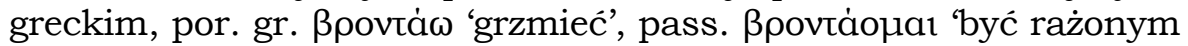
piorunem'. W obu powyższych formacjach dostrzegamy rdzeń indoeuropejski na stopniu apofonicznym (pie. * $g^{u}$ rom-), rozszerzony o sufiks intensywno-iteratywny ${ }^{*}$-tā- $\left(<\right.$ pie. ${ }^{*}$-teh $\left.{ }_{2}-\right)$.

8.5. Stosunkowo nieliczne ślady rdzenia * $g^{u} r e m$ - można odnaleźć w językach nowoirańskich, np. orosz. grand 'grzmot, grom; burza, nawałnica', bal. g(a)rand 'grzmot (piorunu)', sist. grand 'ts.' < irań. "grantā f. 'grzmot, grom, burza z piorunami' < pie. " $g^{u}$ rom-téh ${ }_{2}$-f. 'grzmot, grom', por. gr. ßpovtn่ f. 'grzmot, porażenie piorunem, odrętwienie'. W językach staro- i średnioirańskich zdecydowanie dominują derywaty urobione od rdzenia ie. ${ }^{*} g^{h}$ rem-.

8.6. Języki bałtyckie, podobnie jak słowiańskie, zawierają dość liczne formacje semantycznie zwiazane $z$ grzmotem i hukiem piorunu, które należy wywodzić od rdzenia ie. ${ }^{*} g^{u} r e m-$ (nie zaś ie. $\left.{ }^{*} g^{h} r e m-\right)$. Nie można jednak wykluczyć ewentualności, że w językach bałtyckich mogła nastapić wtórna kontaminacja formacji derywowanych od obu omówionych rdzeni indoeuropejskich (ie. * ${ }^{h}$ rem- $\mathrm{x}{ }^{*} g^{u}$ rem-).

które dwadzieścia dwa lata później porzucił na rzecz odmiennej pary odpowied-

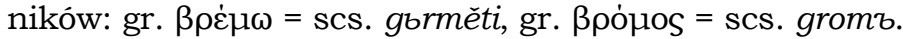




\section{Skróty}

act. - strona czynna (activum); adi. - przymiotnik (adiectivus); afg. - afgański; ang. - angielski; awest. - awestyjski; bal. - baluczi; brus. - białoruski; celt. - celtycki; chorezm. - chorezmijski; chot. - chotański; cz. - czeski; dat. - celownik (dativus); dial. - dialekt(alny); dig. - digorski dialekt języka osetyńskiego; dłuż. - dolnołużycki; f. - rodzaj żeński (genus femininum); głuż. - górnołużycki; goc. - gocki; gr. - grecki; hom. - homerycki; ie. - indoeuropejski; irań. - irański; iroń. - iroński dialekt języka osetyńskiego; iszk. - iszkaszim; lit. - litewski; łac. - łaciński; łot. - łotewski; m. - rodzaj męski (genus masculinum); n. - rodzaj nijaki (genus neutrum); niem. - niemiecki; npers. - nowoperski; orosz. - oroszorski; oset. - osetyński; part. - imiesłów (participium); pass. - strona bierna (passivum); perf. - perfectum; pie. praindoeuropejski; pgerm. - pragermański; pl. - liczba mnoga (pluralis); płd. - południowy; płn. - północny; por. - porównaj; praes. - czas teraźniejszy (praesens); psł. - prasłowiański; refl. - forma zwrotna czasownika (reflexivum); ros. - rosyjski; scs. - starocerkiewnosłowiański; sist. - sistański; sła. - słowacki; sogd. - sogdyjski; stang. - staroangielski; stcz. - staroczeski; stind. - staroindyjski; stnord. - staronordycki; stprus. - staropruski; strus. - staroruski; stsaks. - starosaksoński; stwniem. - starowysokoniemiecki; s.v. - sub voce; śrdniem. - średniodolnoniemiecki; śrwniem. - średniowysokoniemiecki; tadż. - tadżycki; tr. - czasownik przechodni (verbum transitivum); ukr. - ukraiński; zob. - zobacz.

\section{Bibliografia}

Z. Abramowiczówna (red.), 1958, Słownik grecko-polski, t. I, Warszawa.

Ch. Bartholomae, 1904, Altiranisches Wörterbuch, Strassburg.

H. Bailey, 1979, Dictionary of Khotan Saka, Cambridge.

J. Cheung, 2007, Etymological Dictionary of the Iranian Verb, Leiden-Boston.

R. Derksen, 2008, Etymological Dictionary of the Slavic Inherited Lexicon, Leiden-Boston.

R. Derksen, 2015, Etymological Dictionary of the Baltic Inherited Lexicon, Leiden-Boston.

G. Kroonen, 2013, Etymological Dictionary of Proto-Germanic, Leiden-Boston.

R. Matasović, 2009, Etymological Dictionary of Proto-Celtic, Leiden-Boston.

A. Meillet, 1893, De quelques difficultés de la théorie des gutturales indo-européennes, „Mémoires de la Société Linguistique de Paris” 8, s. 277-304.

A. Meillet, 1905, Études sur l'étymologie et la vocabulaire du vieux slave, Paris.

A. Meillet, 1907, Les alternances vocaliques en vieux slave, „Mémoires de la Société Linguistique de Paris" 14, s. 332-390.

J. Pokorny, 1959, Indogermanisches etymologisches Wörterbuch, Bern-München.

V.S. Rastorgueva, D.I. Edelman, 2007, Ėtimologičeskij slovar’ iranskix jazykov, t. III, Moskwa.

H. Rix (red.), 2001, Lexikon der indogermanischen Verben. Die Wurzeln und ihre Primärstammbildungen, Wiesbaden.

F. Sławski (red.), 2001, Słownik prasłowiański, t. VIII, Wrocław-Warszawa-Kraków. 
W. Smoczyński, 2007, Słownik etymologiczny języka litewskiego, Wilno.

O.N. Trubačev, 1980, Ėtimologičeskij slovar' slavjanskix jazykov. Praslavjanskij leksičeskij fond, t. VII, Moskwa.

M. de Vaan, 2008, Etymological Dictionary of Latin and the other Italic Languages, Leiden-Boston.

K.T. Witczak, 2017, Prasłowiański przyrostek *-tajь $w$ świetle materiału leksykalnego, „LingVaria” 12, 1(23), s. 209-222.

\section{Discussions on the etymology of grom (thunder)}

\section{Summary}

The Polish appellative grom $\mathrm{m}$. 'thunderclap' (< Proto-Slavic *grom $\mathrm{b} \mathrm{m}$. 'thunder, thunderclap, roar of a thunder') should be associated with Greek $\beta \rho$ ó ${ }_{0} \mathrm{~m}$. 'any loud noise; crackling of fire; roar of a thunder; roaring of a storm; rage, fury'. Both these nouns derive from the Proto-Indo-European archetype * $g^{\prime}$ rómos $\mathrm{m}$. 'loud noise; thunder, thunderclap, roar of a thunder' (originally nomen actionis with the meaning 'roaring; thundering', derived from the root

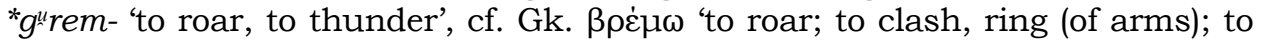
shout, rage (of men)', pol. grzmieć 'to thunder'). The comparison of PSl. *gromb with Gk. xpójos m. 'neighing or whinnying (of horse)' is semantically doubtful.

Keywords: Balto-Slavic languages - etymology - Greek-Slavic isoglosses - IndoEuropean languages - semantics - word-formation

Adj. Monika Czarnecka 